\title{
APP-009 Talin1 is a Novel Regulator of Prostate Cancer Invasion and Metastasis via Activating AKT Dependent Cell Survival Signals
}

\section{千葉大学医学部泌尿器科学 ${ }^{11}$, ケンタッキー大学医学部泌尿器科 ${ }^{2)}$}

坂本 信一 ${ }^{1)}$ ，鈴木 啓悦 ${ }^{11}$, 納谷 幸男 ${ }^{1)}$, 二瓶 直樹 ${ }^{12}$, 今本 敬 ${ }^{1)}$, 荒木 千裕 ${ }^{1)}$, 神谷 直人 ${ }^{12}$, 川村 幸治 ${ }^{12}$, 矢野 仕1)、ナターシャ キプリアーノ゙、市川 智彦 ${ }^{1)}$

【目的】近年、Talin1 は、インテグリンの活性化に不可欠な結合タンパクであることが明らかとなった。インテグリ ンは活性化により、細胞外器質（ECM）との親和性が増大し、細胞内外のシグナル伝達の向上がみられることが知 られている。我々は、今回、Talin1 が前立腺癌の Microenvironmentに抢いて、腫瘍浸潤、転移においてどのよう な役割を果たすのか解析した。【方法】Apoptosisの解析とタンパク発現は、Flow Cytometry と Western Blot 法を 用いた。マウスの肺における転移解析は、ヌードマウスの Tail Vein Injectionを用いた。前立腺癌発達にともなう Talin1の発現は、TRAMP（Transgenic Mouse Model of Prostate）マウスの癌発達年齢別（6から 31 週）に解析し た。前立腺癌患者標本は、リンパ節転移部位を含めた Tissue Microarray（317 検体）を用いて解析した。【結果】 Talin1 低発現の PC-3 細胞に扔ける Talin1 の安定発現 は、インテグリン依存的に、FAK（Y397）、AKT（Ser473） およびSRCを活性化し、前立腺癌細胞株（PC-3）の Cell Migration, Invasionの能力を促進した。また、これらの作 用は、AKT 阻害剂を加えることにより、優位に抑制された（P<0.05）。Talin1 の細胞内シグナルの活性化には、 Integrin $\beta 3$ が主に関与していた。Talin1 高発現の DU145 細胞における、ShRNAによる Talin1 ノックダウンは、優 位に Cell Migration おょよび Invasion の能力を抑制した。インテグリンと独立した作用として、浮遊細胞に㧤いても、 Cell Survival Signal に関与する GSK-3 $\beta$ を活性化して、細胞接着消失に伴う Apoptosis（Anoikis）抵抗性を示した。 Talin1のShRNAによるノックダウンは、ヌードマウスにおける前立腺癌細胞の肺転移を優位に抑制した $(\mathrm{P}=0.028)$ 。 TRAMP マウスに扔いて、Talin1の発現は、マウスの年齡増加（12 週から 31 週）にともなう前立腺癌の進行及び転 移とともに上昇した。前立腺癌患者標本において、Talin1の発現は、BPH や正常部と比較し腫瘍部及び転移巣にお

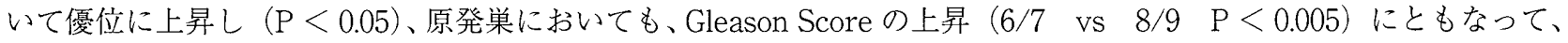
優位に発現の上昇が見られた。【結論】Talin1 は、インテグリン依存的にFAK/AKTを介して腫瘍浸潤を促進し、 インテグリン非依存的に Anoikis Resistance を通して遠隔転移に関与していることが明らかとなった。今後、前立腺 癌進行のマーカーとしての可能性が示唆された。

\section{APP-010 ELOVL7, a Novel Elongation Enzyme of Very Long-chain Fatty Acids, Involves in PC Cell Growth through Metabolism of Saturated Fatty Acids and Steroids}

\section{高知大学医学部泌尿器科学1), 東京大学医科学研究所ヒトゲノム解析センターゲノムシークエンス解析分野2), 理化学研究所脂質生物学研究室 ${ }^{3}$, 京都府立医科大学医学部泌尿器科学 ${ }^{4)}$, 岩手医科大学医学部泌尿器科学 ${ }^{5)}$ 田村 賢司 ${ }^{1.2}$ ，牧野 麻美 ${ }^{32}$, フランソワーズ ウランマツダ3)，小林 俊秀 ${ }^{32}$, 降幡 睦夫 ${ }^{12}$, 鄭 秀蓮 ${ }^{22}$, 蘆田 真吾 ${ }^{1)}$, 三木 恒治 ${ }^{4}$, 藤同 知昭 ${ }^{5)}$, 執印 太郎 ${ }^{12}$, 中村 祐輔 ${ }^{2)}$ ，中川 英刀 ${ }^{2)}$}

In this study, through our genome-wide gene-expression analysis of clinical Prostate cancer (PC) cells, we identified a novel lipogenic gene, ELOVL7, as an over-expressed gene in PC cells. Immunohistochemical analysis confirmed the elevated expression of ELOVL7, a 281-amino-acid protein possibly involved in elongation of long-chain fatty acids, in PC cells compared with that of normal prostate epithelium. Knockdown of ELOVL7 expression by siRNA resulted in drastic attenuation of PC cell growth, suggesting that ELOVL7 expression could be essential to cell viability of PC cells. ELOVL7 expression was regulated by androgen pathway through SREBP1, as well as other lipogenic enzymes. In-vitro fatty-acid elongation assay and fatty-acid composition analysis indicated that ELOVL7 was preferentially involved in fatty-acid elongation of saturated very long-chain fatty acids (SVLFAs), which are abundant in animal meat diet. Lipid profiles demonstrated that knockdown of ELOVL7 in PC cells mainly affected SVLFAs in the neutral lipids, such as cholesterol ester and triglyceride. Interestingly, focusing on cholesterol ester as a source of de novo steroid synthesis, we showed that ELOVL7 affected de novo androgen synthesis in PC cells. These findings suggest that ELOVL7 could be involved in growth and survival of PC cells through the metabolism of SVLFAs and their derivatives, and thus, could be a key molecule to elucidate the association between fat diet intake and prostate carcinogenesis, and also a promising molecular target for development of new therapeutic or preventive strategies for PCs. 